Article

\title{
Developing Strategy for Water Conflict Management and Transformation at Euphrates-Tigris Basin
}

\author{
Sameh W. H. Al-Muqdadi
}

Faculty of Geoscience and Geo-Engineering and Mining, TU Bergakademie Freiberg, 09599 Freiberg, Germany; almuqdadi@web.de

Received: 17 August 2019; Accepted: 25 September 2019; Published: 29 September 2019

\begin{abstract}
Developing water technology and management systems is not sufficient to cope with the water shortage, where political decisions might be considered as a critical element in this context. The Euphrates-Tigris basin has been suffering for decades from political instability and mismanagement. The tension over the water allocation that was on the negotiating table since the 1960s ended with no substantial agreement between the riparian countries (Iraq, Turkey and Syria). The objective is to evaluate the impact of the political dimension by creating a conceptual model for the hydropolitical cycle, addressing the importance of the negotiation concepts to reach an agreement; the research also aims to develop a strategy that might support the transformation from conflict to collaboration. The approaches of situation map and systems thinking have been implemented to build the model. The tools of negotiation skills have been adopted to assist the water conflict. The results describe the challenges within different levels and demonstrating the hydropolitical cycle and adding a sustain toolkit to the theory of water conflict and transformation management. Moreover, the paper produces the structure and workflow of establishing the Global Water Security Council.
\end{abstract}

Keywords: water conflict and transformation; hydropolitics; water hegemony; water governance; water policy; water security; Euphrates and Tigris; Middle East

\section{Introduction}

Water is no longer limited to being a key factor for food security, health concerns and environmental challenges, rather it now plays a significant role in different vital sectors, such as economic and social impact, national security and also has lately obtained distinctive political weight as a source of power. The Euphrates-Tigris basin (ETB), has been suffering from the water hegemony, in particular for the downstream countries. Generally, the disputes over water resources have been on the peak, since the South Eastern Anatolian Project (GAP) has been accomplished by the upstream region, where massive dams have been constructed to control water. Water stress has dramatically risen. Currently, the Aliso dam is ready to store water; many implications might arise in the near future on different levels: environment, health, food security, demographic changes, national security, which are all considered as important issues to combat. In addition, the region faces serious challenges due to the impact of climate change, environmental degradation and massive urbanization. This highly complex admixture demands holistic and creative approaches. Ultimately, there is a global and regional need to design a structured strategic plan for water governance; the design should be integrated with a political perspective to give legitimate power and priority. Several insightful studies were analyzed that illustrated the challenges of water conflict and the possible solutions to reach agreements. Carkoglu, Ali, and Mine Eder [1] highlighted the underlying issues and reasons behind the water dispute in the ETB. The authors illustrated two major dimensions of the conflicts: the political dimension, where GAP project is important for local parties, utilizing traditional patronage linkages, and national security and integration of the region to the rest of the country. El-Fadel et al., [2] reviewed the historical 
conflict in the basin, as well as different interpretations given by riparian countries to define the basin as comprising international rivers or transboundary watercourses. Additionally, the author came up with an interesting hypothesis whereby the root of the conflict in the ETB is back to the geopolitical order that appeared after World War I. After defeating the Ottoman Empire, Britain and France agreed to sub-divide the Middle Eastern states between them by the Sykes-Picot Agreement on 16th May, 1916. Thus, Syria went under the French rule and Iraq with the British colony against the Ottoman empire. The author believed that this event later revived the betrayal feelings among the Turks towards Arabs. The author explained how to have a compressive and integrated regional plan. Kibaroğlu [3] demonstrated the meetings and agreements between the riparian countries, considering the Joint Technical Committee (JTC) that reflected the level of collaboration between Turkey-Syria and Iraq for a decade (1983-1993). Although the 16 meetings ended in a deadlock, as they could hardly reach a common terminology to identify the rivers and basin, the author emphasized the importance of the JTC step and considered it not at least a useful channel for communication. Daoudy [4] illustrated three concepts for benefit-sharing within the TEB: power, security and sustainability. The work proposed a multi-dimensional model including: the risky areas, environmental challenges and strengthening the economic sector. The outputs show that Iraq is in the high-risk zone, within the riparian countries, followed by Syria, then much less by Turkey. Daoudy [5] also addressed the perspective of negotiation theories, where the upstream countries mostly used the asymmetries of power, military and economic resources. The work showed how Syria effectively used the tactic of issue-linkage with Turkey, where supporting the Kurdish rebels was the key factor to obtain the 1987 agreement related to water allocation. The author implemented a conceptual framework about how to manage the negotiation in situations of power asymmetry. The analysis result of the negotiation showed the distributive type (zero-sum or win-lose game). The negotiation environment was characterized as mixed and integrative. The author also demonstrates the best alternatives to negotiated agreement (BATNA) tools for understanding the power positions of the three actors. Harris, Leila M., and Samer Alatout. Ref. [6] examined the development of the hydropolitical workforce in the different states. The author illustrates the usefulness of a performative approach that would enrich the understanding of water politics and explain how water becomes a focal case by nations, states, and territories. The results showed that water plays a central role in the geopolitics of the Middle East.

Kibaroglu, Aysegul, and Waltina Scheumann [7] stated that the riparian countries expanded their hydropower activities and agriculture sector; this was considered as a major threat to the relationship between the key players in the ETB, who failed to reach mutual agreement. However, the author used the table of Delli Priscoli and Wolf to rate the water disputes and transformation in the region. The results showed improvement in the negotiation level and considered that riparian countries passed stage I, focused on water rights (adversarial negotiation) and moved to stage II (reflexive negotiation), focused on water needs. The author believes that the fundamental challenge is how to establish a framework to operationalize the multi-agreements that have been made in different aspects. Al Obaidy, Abdul Hameed et al., [8] presented the socio-economic challenges to water sustainability, in particular for Iraq. The work highlighted the needs for a comprehensive national plan. The results showed that the upstream country development projects led to significant degradation of water quantity and quality. The country is facing a major threat in terms of desertification and its political stability is at risk. The authors also emphasized the displacement of population that caused ethnic tension. Hommes [9] discussed the mega-hydraulic project (Ilisu Dam), when it was still under construction, showing coalitions between different actors, illustrating the different dimensional impact of considering the Ilisu Dam as a very sensitive topic in terms of a hydro-social cycle, and the Turkish challenge to get the financial resources. The author believed that the root of dispute dated back to the 1990s due to the Kurdish actions; these actions attracted global attention to the poor treatment of the south-eastern region. Conker $[10,11]$ conducted hydropolitical studies for the construction of the Ilisu dam project. The analytical researches considered an in-depth investigation of the relationship between Turkey and the downstream countries, demonstrating the role of power in transboundary water politics. 
The author proposed a conceptual framework to analyze how power dynamics are working and how they change over time to shape the relationship between the actors.

Lossow [12] gave a holistic overview regarding how water could be used as a weapon, by example of the expansion strategy of the so-called Islamic State of Iraq and Syria (ISIS), when they controlled water by seizing several important dams in the ETB during 2014-2015. The author presented how water could be a sensitive component and effective tool for tactical and strategic reasons, where three essential ways can define using water resources as a weapon by making water shares too little or too much, or of insufficient quantity. The results showed that ISIS had used all the three approaches to have an impact at the local, regional and national levels.

Zeitoun et. al., [13] explored the role of the soft power of hydro-hegemony contexts. The author analyzes the integrative and distributive functions of the ideational power and the advantages of intellectual battles of negotiations and diplomacy, and the non-hegemon could benefit from consideration of asymmetry in soft power to confront the stronger actors. Hussein et. al., [14] proposed two qualitative steps to improve SDG Indicator 6.5.2. The author proposed 1) a pre-operational arrangement phase as an intermediate step to fill the gap between a lack of operational arrangement and the operational arrangement already proposed. 2) Evaluating the agreement deliverables in a reality where showing agreements does not mean that they would be a good indicator for SDG scoring. The two suggested steps would help to reveal the inequitable water agreements and also to promote the actual achievement of formal cooperation. However, the author emphasizes that the application of the steps required considering the DSGs 6.5.2 as a proactive tool in the transboundary cooperation by the United Nations.

The objective of this research is to evaluate the post-conflict situation after the GAP dams are in operation, by simplifying the source of power and the weight of the political decisions on the water strategies, highlighting the value of negotiation as a substantial tool to reach a mutual agreement. The ultimate goal for the current work is to create a conceptual model for the hydropolitical cycle and describe the cycle phases, adding the sustainability stage to the theory of water conflict and transformation management. The outcome should include establishing an entity with a comprehensive framework supporting the United Nations law on non-navigational use of watercourses, the entity aimed at governing the water resource and promoting cooperation between the riparian countries.

\section{Materials and Methods}

\subsection{Global Factsheet}

Analyzing the water conflict in the ETB needs a deeper understanding of the global factsheets of the water sources. One of the main sources of the power of water is how this element interacts in daily life with multiple functions and by influencing different sectors (Figure 1). Water is considered as a major concern for management and urbanization, where $90 \%$ of all natural disasters are water-related [15]. By 2025 about 2/3 of the population of the world expected to have limited access to freshwater [16]. About $50 \%$ wetland has been lost in the last century; by 2030 it has been estimated that 24 million people will be displaced due to water scarcity and climate change influence [17]. The demand for global food production will be increasing dramatically to reach approximately $50 \%$ to feed the 9 billion people [18]. Conversely, 20\% of the world's aquifers is being over used [19]; 50 children are dying daily due to poor sanitation and unsafe drinking water [20]. 


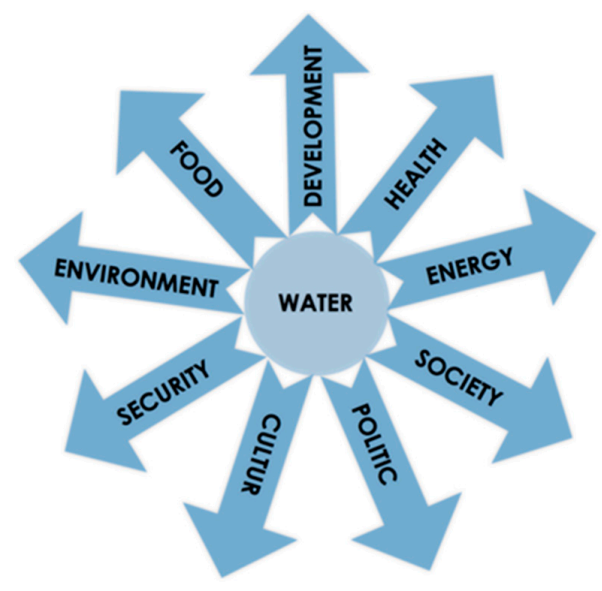

Figure 1. Water and influenced sectors.

\subsection{Region of Interest}

Historically, the Mesopotamian region witnessed the first water conflict, as well as early agreements in context of water resources [21,22]; (Figure 2). Regionally the water tension was recorded after the political border was set as a result of World War I, where three countries emerged-Iraq, Turkey and Syria. Hence, the water tension could be considered here as a collateral damage for the new order in the region (Figure 3); the history of disputes has been intensively described by several authors [5,23], where the first agreement between Iraq and Turkey dated back to 1926 [24], followed by a friendship treaty in 1946 [25]. However, three decades later (1962-1993), about 45 negotiation rounds had been conducted between the three countries (Iraq, Syria and Turkey) that ended without any solid agreement between them, and only two major events of conflict happened: in 1974 between Syria and Iraq [26,27]; and in 1990 between Syria and Turkey [28]. Currently, after the GAP project has been completed, the negotiation approaches and bargaining power positions for both downstream and upstream countries will change; thus, a new strategy needs to be developed to ensure peace and reach mutual agreements.

Turkey, at state level, has three classical challenges: 1) joining the European Union; 2) energy shortage; and 3) the rebel movement and political instability in the Southern region. Since joining the European Union is no longer a priority for Turkey [29], the control of water resources and acting as a water-bank for the region would solve not least the other two challenges.

Turkey faces a shortage in energy, where oil production can only cover 17\% of the local demand [30]; Turkey still does not have their own nuclear power plant, where the lion's share for generating energy is from gas (over 35\%) and hydropower (over 32\%) [31]. The GAP project is mainly for generating power, where the expected annual capacity will be 27 billion $\mathrm{kWh}$, which is considered $45 \%$ of the potential water-energy in Turkey. The anticipated plan for 2020 involves increasing the hydropower capacity to 34,092 MW [32].

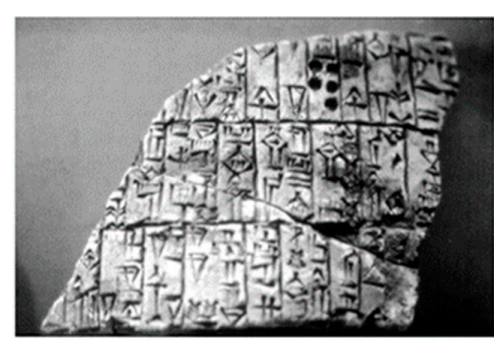

(a)

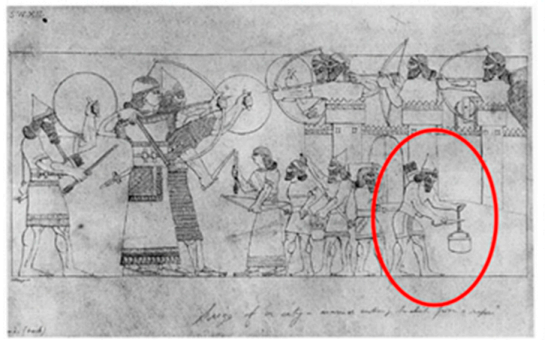

(b)

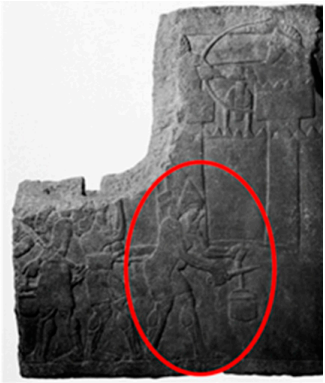

Figure 2. (a) Ancient treaty on clay in 2500 BC, when the two Sumerian city-states made an agreement related to the Tigris River. (b) An ancient warrior cuts the rope of the bowl as a sign of water siege. 


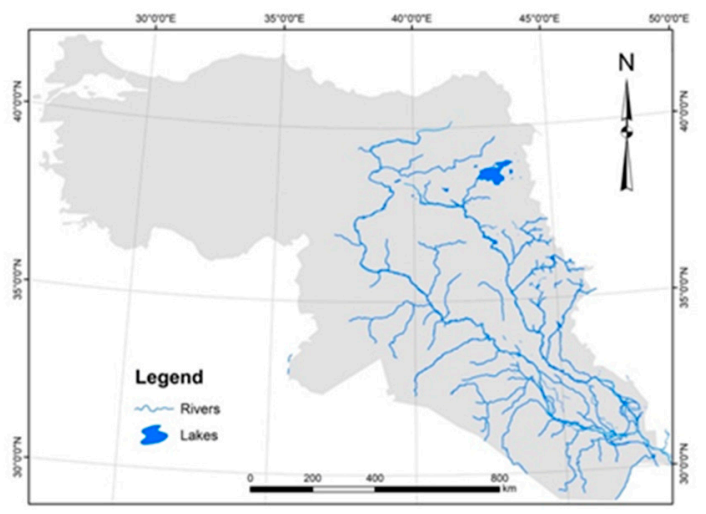

(a)

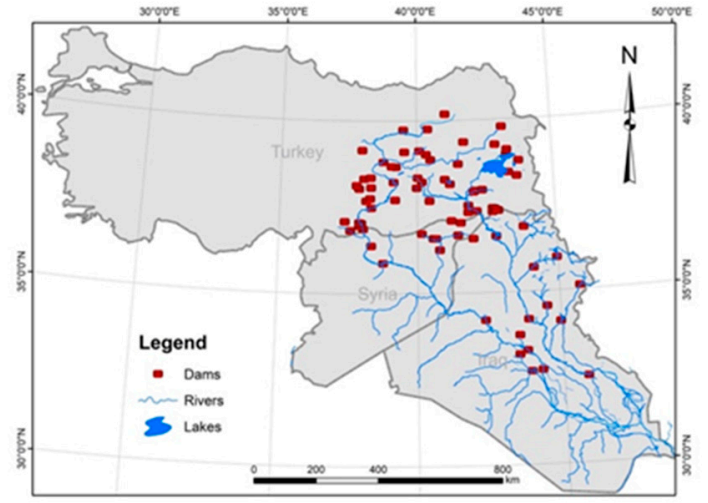

(c)

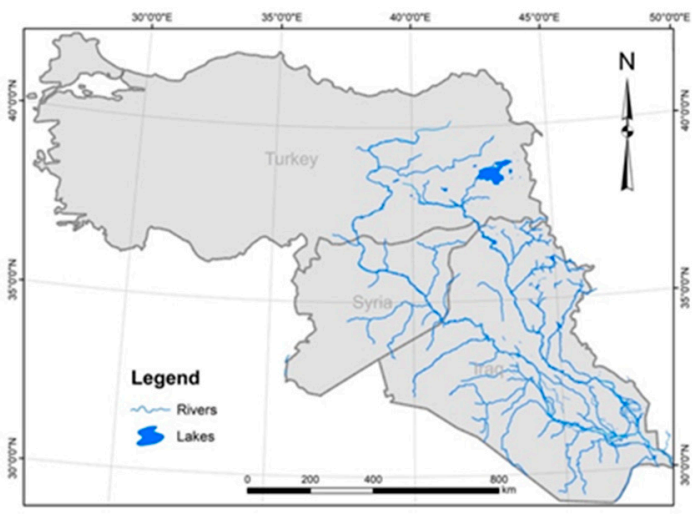

(b)

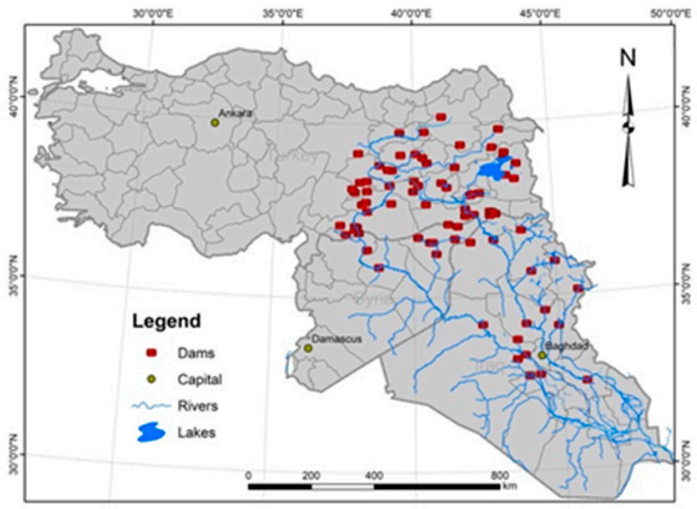

(d)

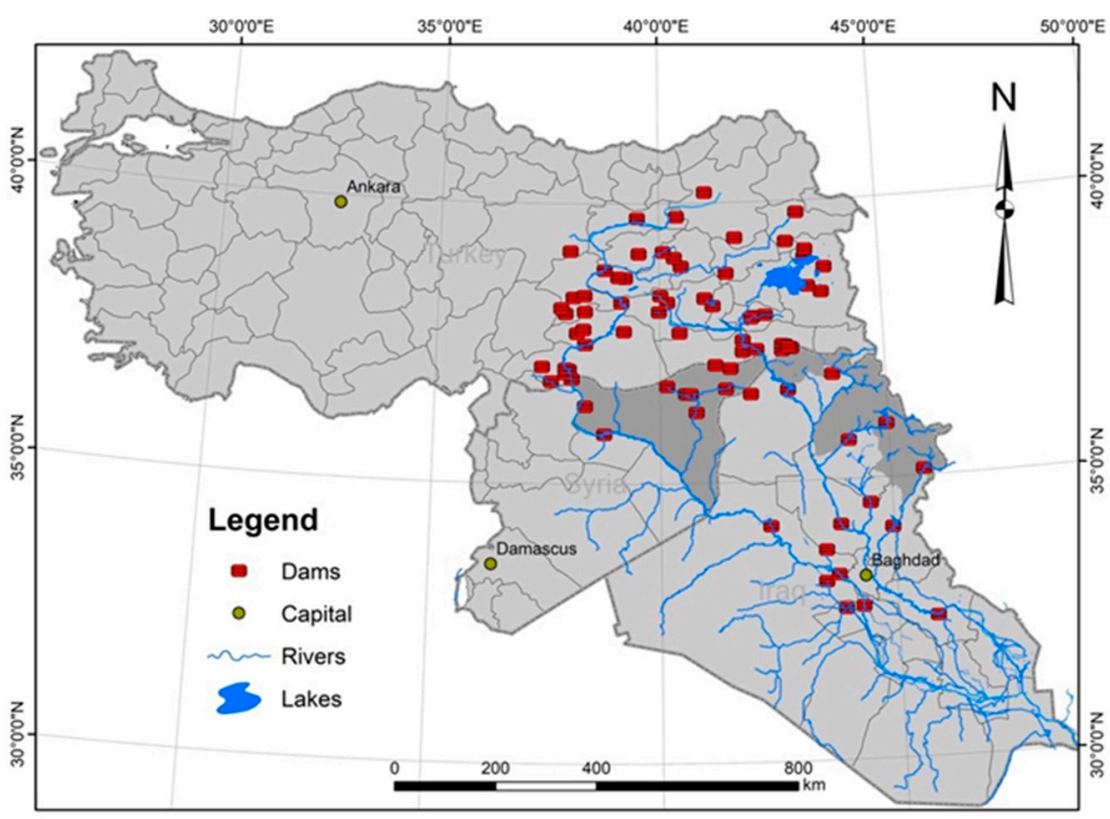

(e)

Figure 3. Geopolitical development of the Euphrates-Tigris basin (ETB) region (a) without political borders during the Ottoman Empire, (b) with countries' political borders after the Ottoman Empire, (c) with current major dams, (d) with current states' administrative borders, (e) with official Kurdistan regional government in Iraq and unofficial East Euphrates river of Syria, 2019.

For four decades, the rebel group known as Kurdistan Workers' Party (PKK) is in a conflict with the Turkish government to obtain independence or Kurdish autonomy; the unstable region has been 
chosen to establish the GAP project covering nine provinces that covers $10 \%$ from Turkish territories and over $10 \%$ from the country's population. The political parties in the early 1990 s recognized that the percentage of population growth in the GAP region is about $80 \%$ more than the rest of the country with the lowest gross domestic product (GDP) and it is in high demand for development [33]. Over $95 \%$ from the registered voters voted for one party or independent candidate; hence, politicians started thinking about a mobilized voting approach [1]. Therefore, it was decided to choose this region for the multi-dimensional project, where 3.5 million people expected to get jobs, which is $40 \%$ from the GAP region population [33]. Eventually, the project will enhance the socio-economic conditions, improve overall living standards and create stability in the region in the context of the Kurdish case, where the government believes that investment in GAP will undermine the incentives of the rebel movement [34].

Therefore, the importance of controlling water resources and establishing GAP as a national security project basically stems from the strategic and comprehensive plan for Turkey to mitigate the challenges of energy shortage and rebel groups; it could also be to expand its alternatives toward joining the EU in the future.

Syria supported the PKK, providing them with logistical support to force Turkey to sign the 1987 protocol and agree to provide Syria with $500 \mathrm{~m} 3 / \mathrm{sec}$ of water, followed by signing a security protocol of 1992, also emphasizing the same water allocation arrangement agreed upon in 1987. The Adana agreement in 1998 opened the door for vast cooperation between the two countries within different levels and the water share reached near double that of the 1992 agreement $(982 \mathrm{~m} 3 / \mathrm{sec})$ [1]. The period between 1998-2011 witnessed an ideal relationship between both countries as a result of the Adana protocol and had the incentive of mutual interest. In the middle of March 2011, when the Arab spring reached Syria, the relationship between both countries was led to a new stage of dispute, where Syria played the PKK card against Turkey once again and Turkey also played an important role in establishing the Free Syrian Army (FSA), and all previous agreements and protocols collapsed. Thus, it is clearly seen that although water triggered the disputes, at the same time it was also the root and key that enabled to reach the 1998 security protocol, followed later by many productive agreements in terms of water cooperation.

\subsection{Methods}

Secondary data from the recent studies and literature have been collected, along with personal contact and meetings. The systems thinking and situation map approaches for Duboz et al., [35] have been used to illustrate the linkages between multiple actors over the water resources. The situation maps show the possible conflicts and cooperation identifying the weaknesses and strengths. This approach is used to better understand the complex cases by introducing the principals and players, defining the structure of the problem and not least supporting an experimental cycle. This approach will be used in the current research as a tool to reflect on the water influence, local authority interaction and the hydropolitical cycle.

In the negotiation philosophy different concepts will be used, such as: categorizing the issues and the level of discussion by Bacharach [36]; realize the alternatives for oppositions BATNA and the Zone of Possible Agreement to illustrate the reservations and aspirations for each party by Fisher et al., [37]; and the bargaining power to identify the quality and availability of the alternatives by Bacharach and Lawler [38]. These concepts and principles will be practiced on the ETB.

Wolf [39] described the stages of water conflict management and transformation. This theory will be implemented for the region of interest to clarify the stages that lead to transformation, in addition to adding a new phase to the theory that would guarantee the sustainability of the entire regime. The role of incentives will be proposed in three different layers: (1) security, (2) economic, and (3) scientific collaboration. Reactivate the Joint Technical Committee (JTC), long-term economic agreements by establishing the free trade zone (FTZ) and contracting a 3rd party to mitigate the risk of conflict and to bridge the lean time. The study will develop a conceptual model utilizing intellectual structure; the model will support the centralized system and try to consolidate and organize the framework in a 
global level, this might help to secure a smooth transformation; where a solid structure for a global entity will be recommended to minimize the risk of water control.

\section{Results}

\subsection{Water Impact}

Globally, the map of challenges to manage the water resource is rather complicated due to the fact that water is no longer limited to food or health security, but it rather interferes with various sectors in daily life. Figure 4 shows at one glance the major sectors that affect water significantly: health, environment, hydropolitics, economy, management, climate change, governance and urbanization. Each sector has a sub-division to reflect the impact of water challenges. The current paper focused on the hydropolitics sector and conflict transformation.

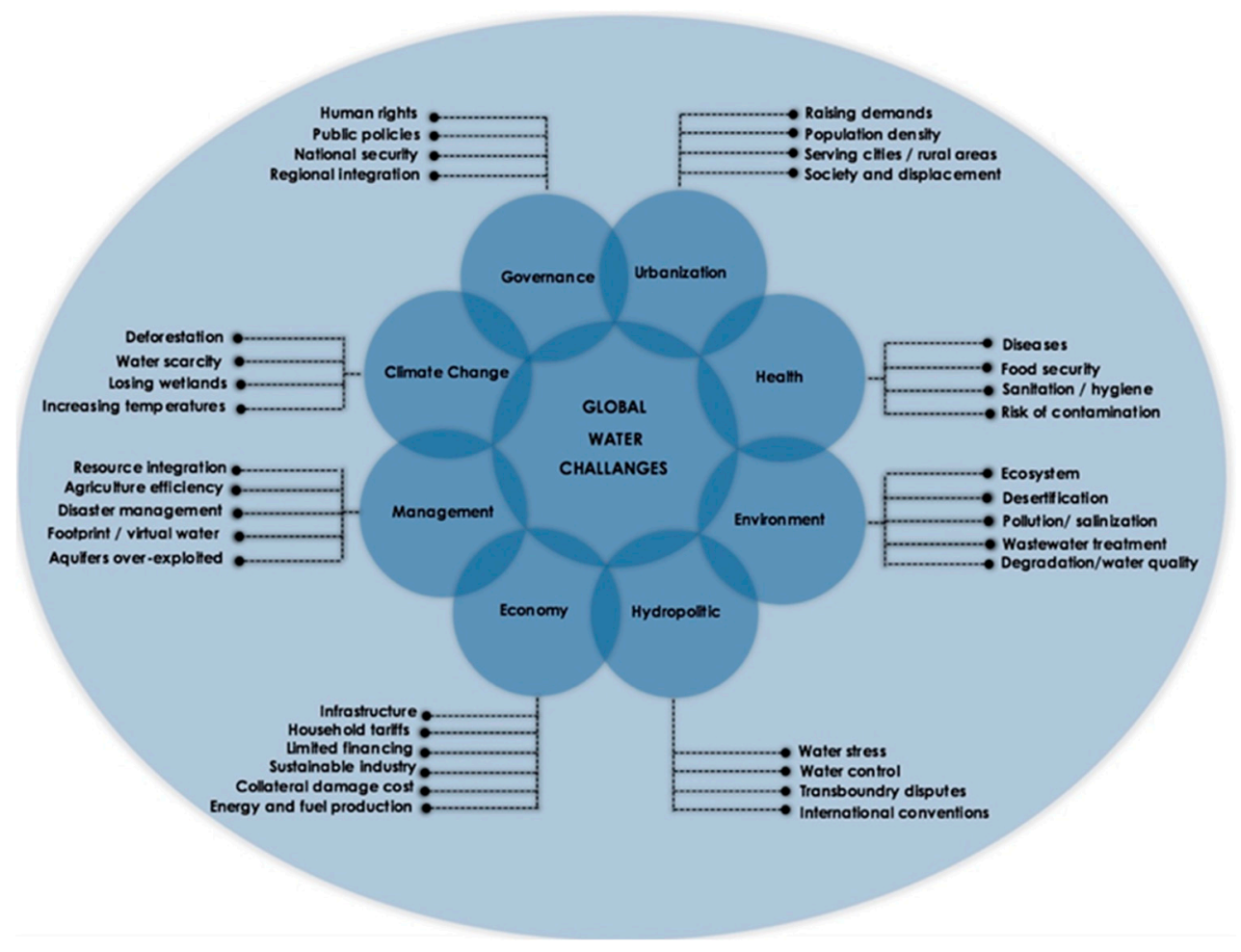

Figure 4. The major sectors that affect the water significantly.

The ETB downstream countries form a semi-arid region, where three sources of challenges may be considered: internal challenge (water management), external challenge (climate change) and the hydropolitics as a third challenge. Although the region is influenced by climate change [40], the internal challenge is the sector worth focusing on, where poor management is wasting the lion's share of water resources. However, the hydropolitics are playing a significant role in the region, and political instability is creating an ideal environment to use water as a political tool (Figure 5).

The ETB is influenced by both global and regional challenges in addition to a special local challenge, where the conflict of interest between the local authorities is tremendous. In Iraq at least 16 key players are interacting with the water resource sector. Besides the poor management, a lack of cooperation and an unclear reporting procedure between the local authorities makes the situation even worse. The absence of one central entity leads this case to be more complicated than ever. The Figure 6 demonstrates the situation map for the ETB, where three circles of challenges are indicated: the local one represented by different stakeholders and local entities, the regional influence with the riparian countries, and the global one showing the broader challenges on the international level. 


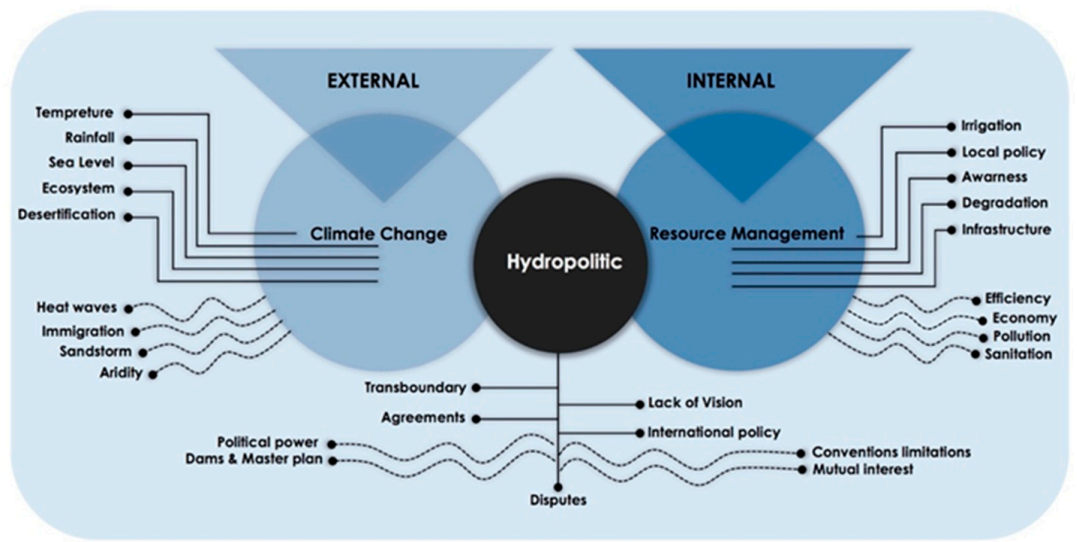

Figure 5. The ETB and regional scale challenges.

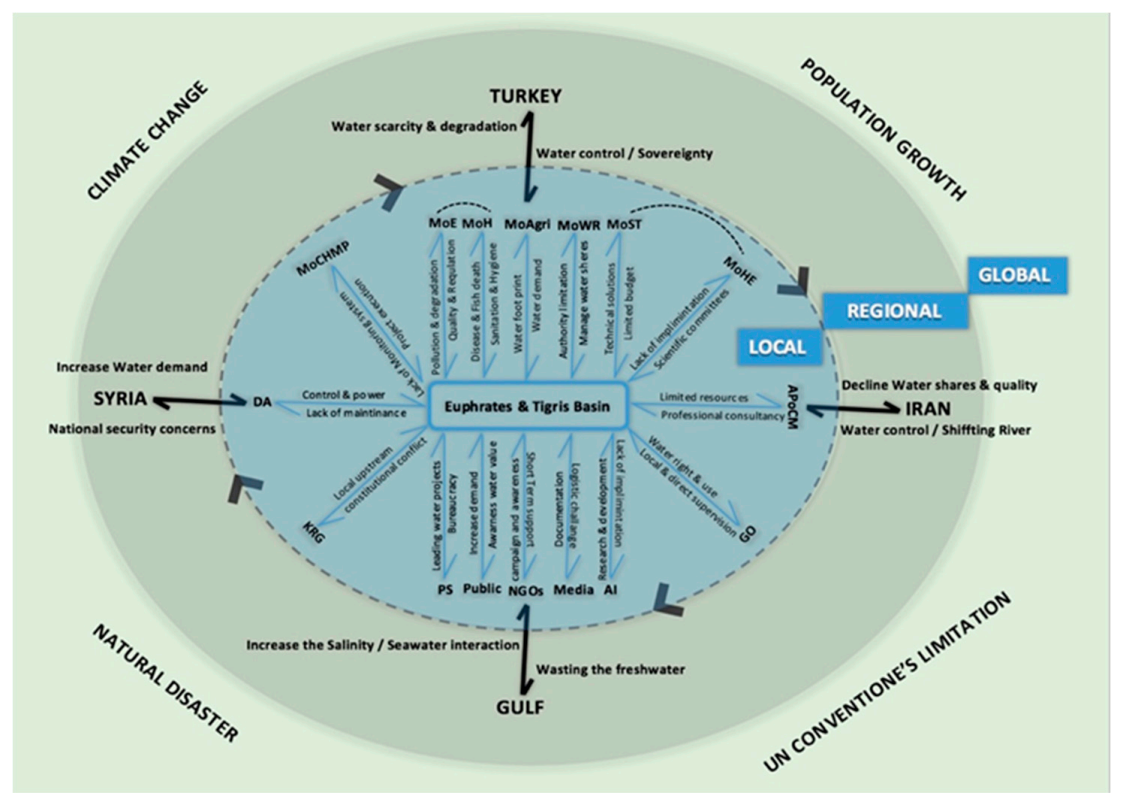

LEGEND:

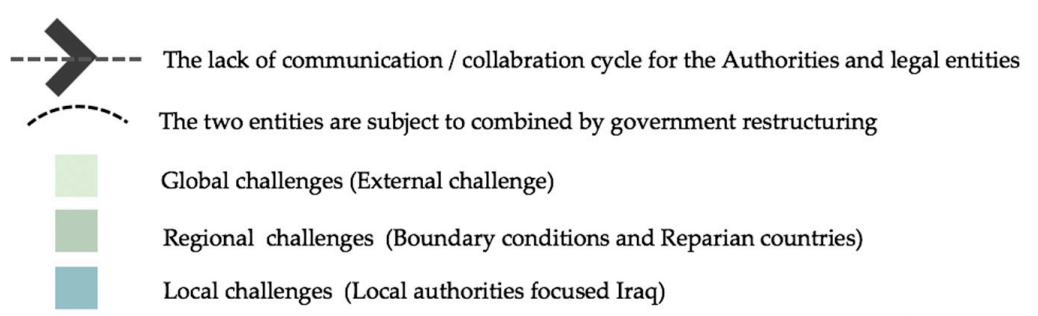

MoCHMP: Ministry of Construction, Housing ,Muncipalities and Public work

APoCM : Advisor to the Presidency of the Council of Ministers

MoHE: Ministry of Higher Education

MoH: Ministry of Health

MoE: Ministry of Environment

MoAgri: Ministry of Agriculture

MoWR: Ministry of Water Resource
MoST: Ministry of Science and Technology

NGOs: Non Govermental Orgnization

GO: Governmental Office

AI: Academic Institutions

KRG: Kurdistan Regional Government

PS: Private Sector

DA: Dams Authority

Figure 6. Situation map in the ETB. 


\subsection{Core of Challenges}

The conflict over water resource allocation in the ETB could be briefly summarized by five sectors where the current research will focus on hydropolitical and negotiation levels as follows:

\subsubsection{Limitation of International Law}

The UN conventions for natural resources [41] and the one for International Watercourses in 1997, which has been developed lately, have some limitations. The limitations were deeply described by Priscoli and Wolf [22], stating that the law was poorly developed and unenforceable. It also showed little practical guidelines for allocations-the main reason behind most of the water conflicts. In particular, the principle of equitable use within the international law gives the needs of the present the same weight as those of the past, where the definition of equitable here before the GAP project is totally different than after GAP completion. The absence of a clear definition of acceptable harm is also another shortage.

\subsubsection{Identifying the River/s and Basin}

Till now the three riparian countries in ETB have not agreed on the basic definition of the rivers, like, whether they consider the rivers as international rivers (downstream proposal) or transboundary watercourses (upstream point of view). From the basin perspective, Syria and Turkey considered them as a single water system, while Iraq has asked to treat the rivers separately as two systems. However, after many meetings between the riparian countries, the negotiation in this context has reached a deadlock [7].

\subsubsection{Water Allocation}

Water allocation is the ultimate goal of any riparian country, in particular the downstream countries. It is considered as the most critical topic. Unfortunately, the three riparian countries have to date not agreed on a formula for water allocation. While Iraq and Syria claim there should be 1:1 water share, since both countries believe they are dealing with international rivers, in 1987, Turkey proposed for the ETB a three-stage plan: 1) establishing a joint committee 2) estimating the water need for each country, and 3) providing the water allocation based on needs [3].

\subsubsection{Hydropolitical Influence}

In 1916 by a secret treaty between the United Kingdom and France, the Sykes-Picot Agreement shaped the current political borders for the Middle East. At this moment the story of disputes over the water resources started between the riparian countries. The intensity of this dispute has been gradually increasing over time, especially in the last century due to rapid population growth, geopolitical aspirations and not least socio-economic purposes. The location of ETB, as a part of the Middle East region, is highly influenced by geopolitical events, where several wars have been unleashed and the three riparian countries are currently under re-formation, in particular the downstream countries Iraq and Syria. Hence, this political instability will be reflected directly and indirectly on the natural resource management, especially water as a vital element that is highly required for any sort of development.

The pyramid of developing the natural resource investment and decision-maker influence over the history (DNRIP and DMI) is illustrated in Figure 7, highlighting the importance of the decision-maker orientation and their (the decision makers') acute influence on the chain management by conducting the policies.

Basically, the DNRIP and DMI comprise the following five stages:

- Stage 1: The early investigations for the natural resources and the first industrial revolution in the 1760s, where the nations were looking for raw materials.

- Stage 2: Over time, it has been realized that more manpower is needed to maintain the investigation/extracting of natural resources. 
- Stage 3: Emerging demand for technology and experts that would significantly save time, effort and cost.

- Stage 4: No matter how sufficient the manpower one has or the advanced technology one owns, absence of good management for the chain could damage the system severely; therefore, literature that focuses on resource and supply chain management has significantly increased.

- Stage 5: Even when a solid management system is conducted, without good governance and sophisticated policies, it would likely collapse. Hence, it has been recognized that decision-makers will play a crucial role here in maintaining the entire system. Currently many research studies supported proper governance and policies. This stage is located on the top of the pyramid system to ensure the smooth workflow and mitigate the consequences because the impact of failure at this stage is lethal.

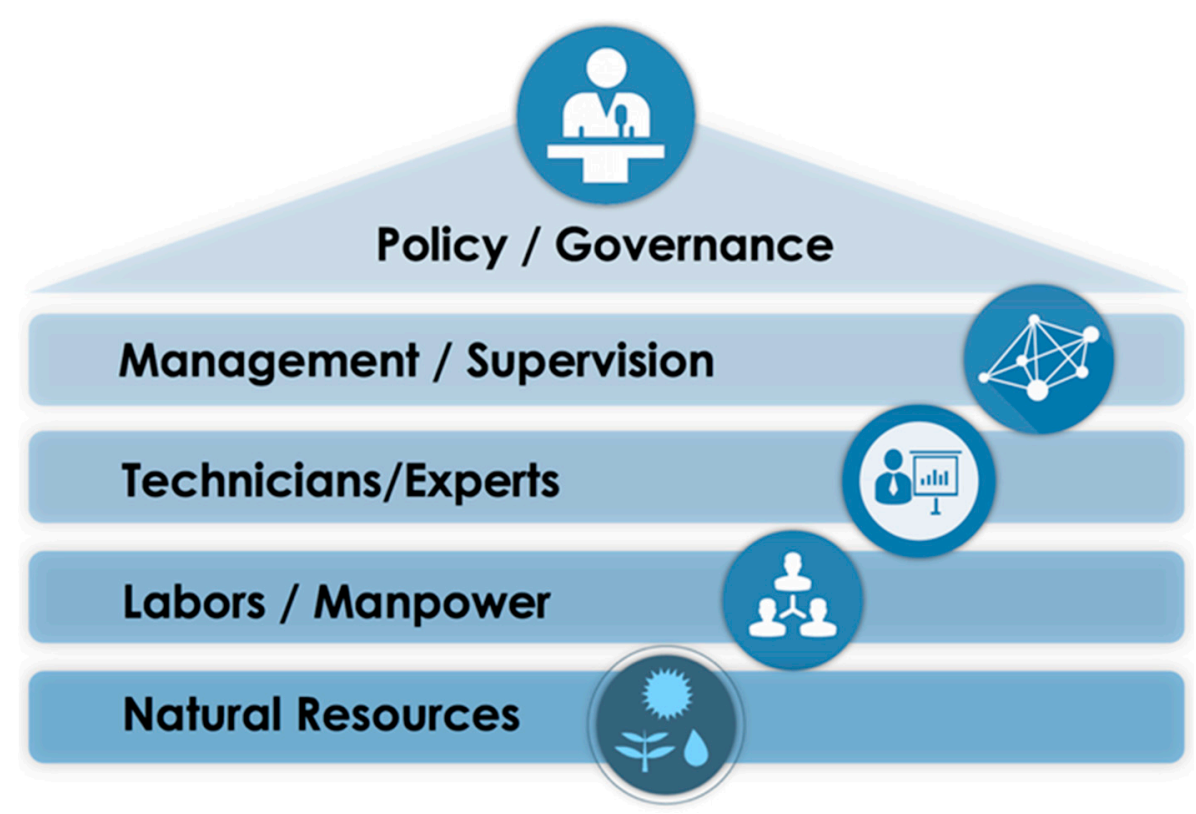

Figure 7. The pyramid of developing the natural resource investment and decision-maker influence.

Generally, hydropolitics has a complicated nexus in terms of the relationship between the upstream and downstream countries, especially if more than two parties are involved. What would be considered as development for the upstream players might lead to tremendous implications for the downstream ones, especially in the absence of cooperation. Five phases have been indicated between the term of development (in the eye of the upstream country) and the action of conflict (the downstream reaction). Figure 8 illustrates the five phases of the hydropolitical cycle and the relationship between the upstream and downstream countries by means of water control and the consequences that follow.

When the upstream country, acting as a sole player, focuses only on the national advantage, the controlling of water resources and building massive dams will then be nothing other than a proper management and development for the region in both dimensions-socially and economically. Here, sovereignty is a common justification used to justify the actions of the upstream country. This is exactly the case of ETB, where Turkey as an upstream state firmly believes that it is practicing its national right. As long as no solid agreement has been reached between the riparian countries, the upstream states will either fail to draw attention to or neglect the impact of the massive dams on the downstream depending on the level of relationship with the downstream countries. Basically, building dams would grow the distrust between the nations like any other barrier; typically, any barrier would cause a miscommunication, the miscommunication will lead to misunderstanding, which will further produce distrust and finally end in a potential conflict [42]. This phase 1 would be called national security and the first move in this stage is always made by the upstream states. 


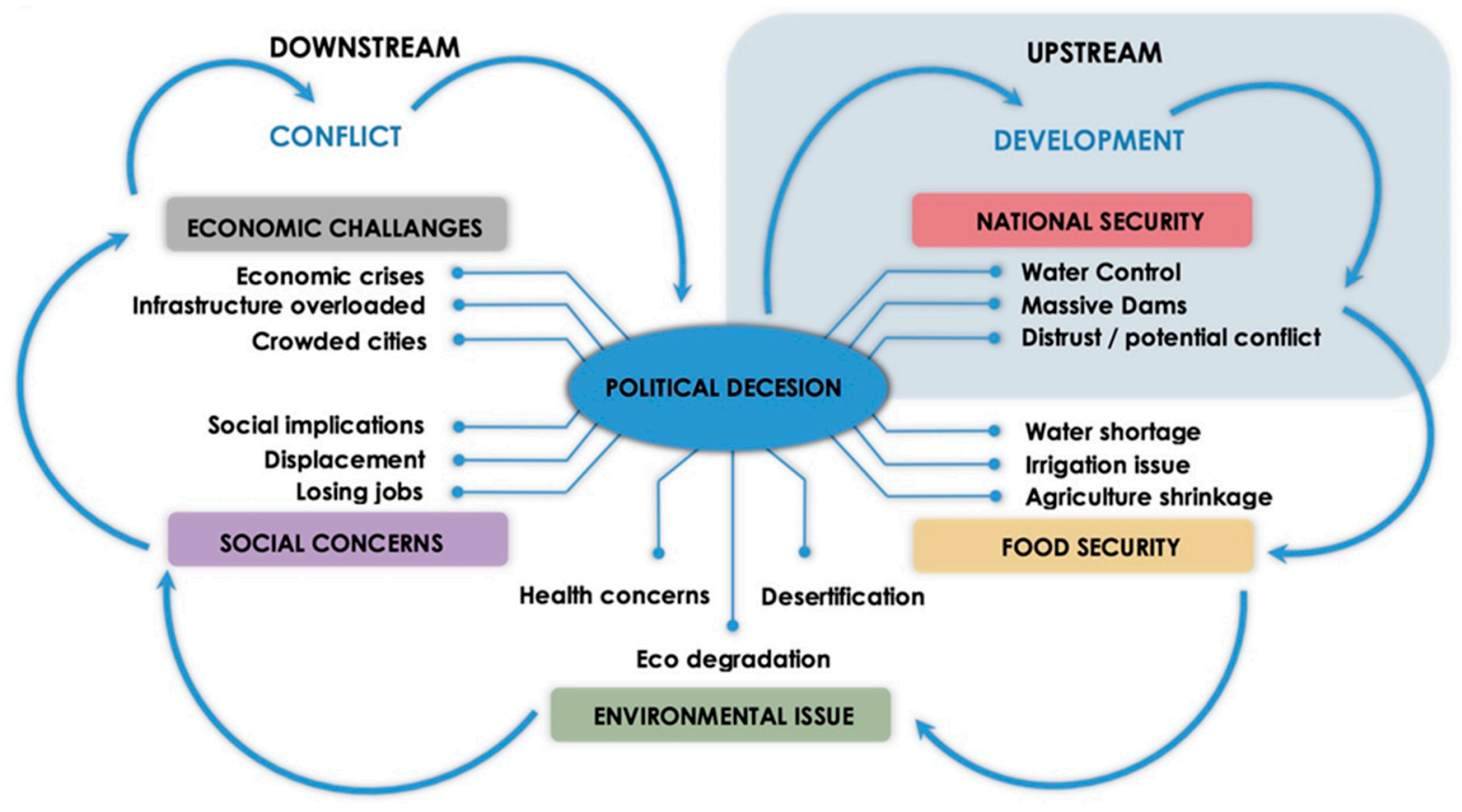

Figure 8. The hydropolitical cycle.

The natural implications for water control will be eventually reflected as water shortages on the downstream countries, where both Iraq and Syria have been suffering for the last couple of decades from the significant reduction of the water shares during the GAP accomplishment. However, the water shortages will logically lead to irrigation challenges, especially if we consider that $60-70 \%$ water resource is used for agriculture. Hence, the agriculture sector will shrink, and this will form phase 2, where the downstream countries will pass through the food security challenge.

The cycle of implications will continue if no agreement is reached during the phase 2 . The next phase will be represented by environmental issues (phase 3), where the downstream region will suffer from desertification, ecosystem degradation and health concerns.

The influence of the development by the upstream region with no consultation with the downstream region will move to the additional zone of negative impact, where farmers will lose their jobs and waves of displacement would be expected. This relocation might lead to severe social implications, adding further burden on the downstream region. In the long run, the impact could even reach the upstream region, when this wave of displaced people is crossing the borders and is being recognized officially as immigrants; this is phase 4 labeled as social concerns.

If the riparian countries still do not reach an agreement, even after phase 4, the social concerns are probably converted to real economic challenge for the downstream region. This is phase 5 , where the cities might be crowded and the infrastructure will be insufficient and overloaded. This phase could end with economic crises for the downstream region, eventually leading to unleash conflict.

The most important indicator in this cycle always starts with a political decision (development) and ends with a political decision as well (conflict). Between this development and conflict chain, a decision is genuinely made at a political level, where scholars have mostly no power to interfere. It is not surprising that Plato in his well-known book the Republic has stated very clearly the high value of the politician as a function, where the zone of impact for the political decision is very large and the decision they make is rather critical and sensitive to the extent of being a milestone for the ages, regardless of whether it is positive or negative.

Many examples exist in the ETB proving the hypothesis that the drying of the marshlands in the 1990s and environmental degradation caused in Iraq was a political decision made under the name of national security $[43,44]$, same as restoring the marshlands after 2003, when the new regime took over. 
There is no doubt that the decision was right from the environmental perspective, but the achievement also has been codified as a success for the new political order [45].

Despite all recommendations being given about the improper location for the Mosul dam, a political decision was made to build it at the current location. The location suffers from a geological setting, where the dam has been built on bedrock of gypsum that is regularly dissolved by water. Since that time, the foundation needs regular cement injection to prevent the cracks from expanding [46,47]. The same applies to the case of the unfinished multi-purpose Bekhme Dam built on the Great Zab, 60 kilometers north-east of Arbil that was never completed due to geopolitical reasons [48].

The clear contradiction in the Iraqi constitution with respect to the governance of water resources between Article 110, Paragraph 8 and Article 114, Paragraph 7 is a political conflict of interest between the Kurdistan Regional Government (KRG) and the central government of Iraq [49]. In September 2017, during the KRG referendum, the KRG president Massoud Barzani clearly stated to the BBC that the next stage after the referendum, i.e., the negotiation with Baghdad, will be over the political borders, water resources and oil [50], where such a declaration would increase first the geopolitical tension and not least the water tension. The riparian countries have been looking at the emergence of a Kurdish autonomy in Iraq as a national threat; both Syria and Turkey have concerns that this Kurdish autonomy might urge the Kurds living in Syria and Turkey to ask for independence. From the hydropolitical perspective, this will also add a new downstream/competitor to the map, where the new player will be involved in making the hydropolitical scene more complicated than ever.

The objective of the GAP project as multi-dimensional purposes, is driven by a political vision $[1,9,51]$, same as the Manavgat River project with the so-called the Peace Pipeline Project suggested in 1986 by Turkey to supply Israel with water [52]. For decades the Syrian government has been using the PKK as a card for bargaining power with Turkey over water shares [5]. The rise of the ISIS has involved the occupying of dams in Syria, then in Iraq to control the water and attain safe shelters [12]. A similar hydropolitical impact model in the region is represented by the empirical case study of the Yarmouk River Basin and the hydropolitical discourses between Syria and Jordan. Where the impact of water dialogues shaping the transboundary water governance and considering the security and geopolitics $[53,54]$ — the list is long where all these hydro-events started and ended with a genuine political decision. Where Zeitoun [13] believes that the future efforts of hydro-hegemony to transform from asymmetrical to equitable water sharing is reliant on the potential leadership.

\subsubsection{Negotiation Level}

The better the negotiation environment over water resources, the better the outcomes in reaching agreements between the riparian countries; negotiation in this context is a tool to reduce the gap between the development and conflict in the hydropolitical cycle and to maintain the risk of implications. However, hydropolitical negotiation is not an easy task. The type of discussion for the academic levels is based on references, facts, logic and statistics; therefore, it is assumed that the environment of any academic discussion would be in a steady state. Conversely, politicians have a more dynamic environment of discussion, since they rely on completely different principles, such as profit and loss, opportunity, advantage and not least negotiation skills. Managing a hydropolitical negotiation is a hard task, because it is considered as a multi-state issue. For over three decades, dozens of negotiation rounds have been conducted between the three countries. However, they have resulted in no solid mutual agreements in terms of water quantity or quality. One of the reasons for the failure of reaching agreement between the riparian countries is the poor negotiation environment, where the relationship between the three countries could be classified as complex for several reasons:

- Multilateral players and multi-layered challenges for the ETB.

- A century of arguing over water allocation and sovereignty.

- The tangible bargaining power along with the dynamic political environment of the region.

- The basin segmentation where Turkey is the ultimate upstream country and Syria along with Iraq as downstream nations, but at the same time, Iraq is considered as a downstream nation 
for Syria; also, Iraq is considered the end-user for Euphrates after flowing from Turkey crossing Syrian territories.

- The mixed negotiation environment between the riparian countries where national security and political agendas meet with socio-economic challenges, giving multi-dimensional challenges for any possible agreement.

Prioritization and categorization

One of the major shortages for not reaching strategic agreements is the prioritization of the partnership concept, where the priority of any mutual agreement would be the return on investment, while generally speaking, the ETB negotiations and agreements were accompanied with a competitive environment driven by who is leading and a win-lose approach. Therefore, the priority was for domination, followed then by the return on investment in the second place. A good example here is of Iraq and Syria; although both countries for decades were ruled by the same political party (the two wings of the Al-Ba'ath party), the history between both is very rich in terms of political conflict over who would command. Likewise, agreements over water resources are rarely reached. This would be in agreement with the hypothesis of [5,7], where the negotiations were characterized by a fluctuating environment driven by the zero-sum approach (win-lose) focused more on rights, rather than mutual interests.

Obviously, the negotiation environment lacked categorizing the issues, where the discussion often happened at different levels, focusing on the past and broad issues, rather than addressing specific ones. Where the upstream countries insisted on sovereignty and Syria on shrinkage of agriculture sector, Iraq focused on the Mesopotamian heritage rights. However, the most valuable step was establishing the JTC that added to the negotiation a significant value and feasibility, for the following reasons: 1) a step that led to bringing the key players on the same level of discussion; 2) it was the first try to drag the negotiation aspect from the political level to a technical level.

The first move and the negotiation attitude

The opening move has been initiated by the upstream region by starting the GAP; with this step, the upstream region has already shaped the rules of negotiation to be limited for water allocation; to do or not to do the GAP was not even a negotiated subject. Right after the strategic decision of the GAP, the upstream region was looking for the first move from the opposition and act accordingly. The downstream then mostly did the opening move, since they were in a calming position. This tactic along with the political instability of the downstream and limitation of international law served the upstream country to gain time and complete the GAP successfully.

The negotiation attitude plays a significant role in any type of conflict transformation. It has a profound positive impact on conflict. As Albert Einstein said, "No problem can be solved from the same level of consciousness that created it". So far, the riparian countries have not changed their negotiation attitude; the upstream region is still claiming water sovereignty and the downstream is protesting against water controlling.

The BATNAs and bargaining power

Since bargaining power is all about alternatives, the BATNAs for both upstream and downstream vary with less quality and availability for the downstream. Syria had used the issue-linkage tactic by supporting the rebel group and eventually signed the protocols in 1987 and 1998, respectively. Syria also tried to stop time wastage by preventing external finance from the European Union to be used to accomplish the GAP. Iraq used the card of heritage by successfully listing the marshlands in 2016 as international heritage [55], believing that this should secure a sufficient water share. Iraq also used the benefit-linkage approach by opening the local market for Turkish products, where the volume of the annual trade exchange reached 16 billion USD in 2018 [56], in addition to the Kirkuk-Ceyhan oil pipeline, where the upstream country benefitted from the privileged prices. Due to the sensitive political relationship between the Arab countries and Israel, Turkey tried to expand their BATNAs 
by entering into a security agreement with Israel in 1996. They tried to urge the riparian countries, in particular Syria, to suspend their support for the rebel groups; however, the type of BATNAs along with the less flexibility of changing the negotiation positions are indicated as a fundamental problem that hindered the progress of negotiation and tended more to distributed bargaining and a zero-sum approach (win-lose). It is worth mentioning that involving a third party for the roundtable would add significant value to the discussion and even the future commitments; the previous negotiation rounds lacked a moderator or third party to alleviate the risk of conflict. Global organizations like UN-Water and the World Bank, in addition to some other neighboring countries, would be useful to be added to the package of the negotiation instrument.

Zone of possible agreement

Despite the long history of negotiation, the zone of possible agreement (ZPA) was fuzzy, not least for the downstream, where the reservation (critical level) and aspiration (wishes) were not identified well. What turns a wish into an aspiration is planning well. The reservation of Turkey was to accomplish the GAP and develop the region and its aspiration was to act as a water bank for the Middle East, using the natural resources as a tool for national benefit. The downstream region's reservation was limited to avoid water scarcity and its aspiration was focused on the quantity and quality of water allocation. In a nutshell, Turkey was better prepared with a clear goal and vision.

\subsection{Stages of Transformation Management}

The development post conflict and how to reach the transformation has been described in four interaction phases [22]: negotiation, claiming, collaboration and the geographic scope. Each of these phases passes through four stages.

- Negotiation: The development of this phase was initially built and described by Jay Rothman in 1989 as ARI, standing for: adversarial, reflexive, and integrative; in 1997, the action stage was added to the end with the four stages representing the transformation to become ARIA.

- Claiming: The development was done by Wolf in 1999 by deliberations and described 145 treaties to have the RNBE, standing for: rights, needs, benefits and equity.

- Collaboration: The building skills TSCC was developed by Kaufman in 2002, standing for: trust, skill, consensus and capacity.

- Geographic scope: The reflection of the geographic scope was implemented by Wolf in 2008 by modelling a fictional basin, the so-called Sandus River basin; the interacting example shows how the region has been subsequently developed along with the other above three phases, and the behavior of the geographic scope is reflected and shaped by the negotiation stages, where NWBR stands for nations, watershed, benefit-shed and at the best end with region.

When the geographic behavior tends to be more as nations, the type of negotiation will mostly be adversarial; when the geographic behavior involves acting as a watershed, the negotiation type will be more reflexive, while the negotiation will be integrative if the geographic behavior is a benefit-shed. Finally, if the behavior will be as a region, the negotiation type will be characterized in action.

These vertical and horizontal interactions in the table illustrate the transformation development. No transformation occurs unless the negotiation is developed from adversarial to action, the water claiming changes from rights to equity, the collaboration shifts from building trust to building capacity, and not least the geographic scope behavior is as a region and not as nations.

The ETB has fluctuated over all the four stages above; it has even witnessed the level of action in some events, when few protocols/agreements have been signed and entered into the action state. The action stage was also implemented when the JTC organized several fruitful meetings for technical discussion. However, the practice of the four transformation stages in the ETB also showed a severe shortage; no matter how advanced the level or phase was reached, the state would be fragile due to the absence of political will. Hence, to secure the gains of reaching the action level, adding one additional 
tool called sustainability would be essential. The ultimate objective of this tool is to keep the success of the transformation for the long run or importantly to reduce the risk of collapse in the worst case scenario. The sustainable tools will be represented in Figure 9 as follows:

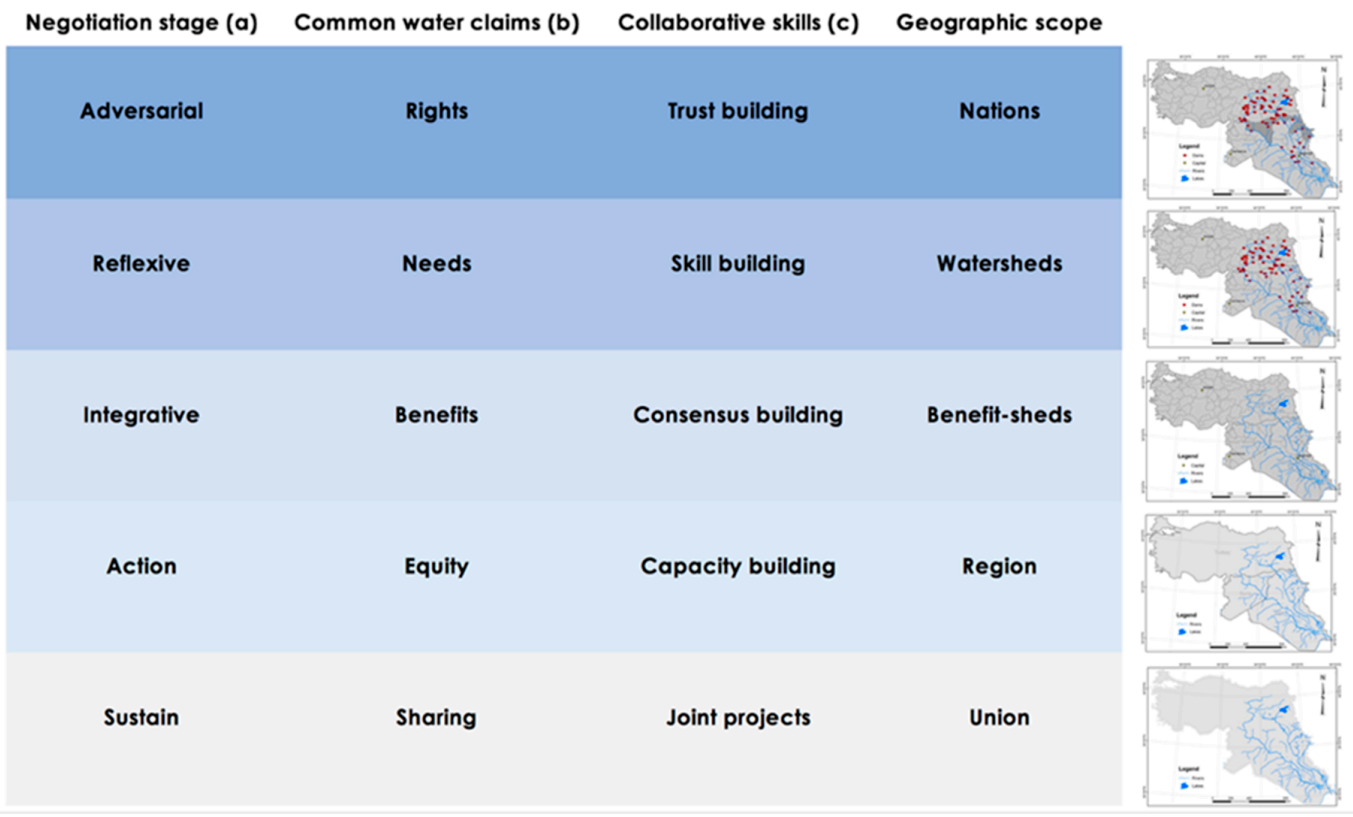

Figure 9. Transformation stages and sustainability, after [22].

It requires adding the sustainable stage to the negotiation phases of adversarial, reflexive, integrative, action-based and sustainable. It also requires adding the sharing stage for the common water claims based on rights, needs, benefits, equity and sharing. It likewise requires adding the joint project for the collaborative skills to be based on trust, skill, consensus, capacity building and joint project. From the geographic scope it requires adding union to become nations, watershed, benefit-shed, region and union.

The transformation then is how to move from adversarial to action; but to secure this transformation we have to move further to sustainable. This sustainability will be consolidated by the role of incentives and the suggested mechanism will be described in the next paragraph.

\subsection{The Role of Incentives}

Cooperation needs to be fed by incentives to be sustainable. Basically, there are several lines of action that could be taken to kick start cooperation on assessing the benefits of the ETB in terms of integrated water management. The suggestion is to tie the riparian countries within three levels: regional security, socio-economic and scientific joint projects as follows.

\subsubsection{Regional Security}

The security concern is highly rated in the region; therefore, cooperation in this context is highly needed at a regional level, especially, after the GAP has been accomplished. Previously, a couple of security protocols have been signed at bilateral levels; in the meantime, a trilateral convention would make much sense.

\subsubsection{Socio-Economic}

Since economic development is a key element, a solid system of commerce by establishing a free zone for trade could be implemented to ensure a better commercial and economic system that would help the region to work together on the economic level. The free-zone has been chosen to be located right on the joint borders between the three countries to guarantee better influence and economic 
outreach. The innovative concept of free economic zones is that companies are able to pay lower taxes or not to pay at all to stimulate the commerce activity. The area could be rented for free trade in which the merchandise could be stored and manufactured or assembled to be ready for export without customs. It is a new order in the region in terms of taxation, customs, navigation, general systems and policies could be coordinated between the riparian countries. The market should be attractive for investors where most of the revenue goes to research and development, to empower the innovation industry and to improve the education system in particular for the ETB water management. These economic initiatives would attract global investors to the region; the benefits of this action will be as follows:

- A trigger for practical collaboration in terms of economic exchange between the riparian countries. The successful economic system will build ties between the three nations and practical commitments that could be used as a springboard for strategic partnership in different levels including water management.

- The revenue of the free zones is suggested to be shared by the riparian countries, and can be used to finance the respective national and regional projects to improve the health of the shared ETB and the ecosystems that nourish the region and provide the basis of its economies.

- The basis for building a friendly environment and special economic zones that would attract the international investment community.

\subsubsection{Scientific Joint Projects}

It is important to reactivate and restructure the good experience of the JTC where a team from each country including scientists, economists, academics and professionals working together, shoulder to shoulder, to share knowledge, to conduct research in terms of natural resource investigation, to determine the value of ecosystem services, to model and manage the shared natural resources, to undertake environmental assessments, and develop harmonized mechanisms for monitoring and data sharing. The expected deliverables of this action will be:

- Knowing in-depth and from different angles the value of natural resources in the region.

- It is a national demand to know the strengths and weaknesses and to better understand the links between the riparian economies and ecosystems, so as to best invest the resources.

- Having reliable and trusted data and records based on wide stakeholder participation to ensure a high level of transparency.

- Developing scientific partnership and building an academic capacity; by this a strong team would be created-a team which might be the core to establish a natural resource institute for peace in the region for the future.

\subsection{Developing International Strategy}

Since the United Nations law on non-navigational use of watercourses has shown limitations, a global and comprehensive strategy for water governance to secure and enforce the cooperation and compliance with the international law principles is needed. The author previously suggested a local framework [23] for the local-scale tailored for Iraq to regulate and manage the water resources in a proper way. The framework focused on centralizing the hydro-decision by establishing a local entity called Water Security Council (WSC). This local entity would be useful for local and internal regulations; by enlarging the concept of this entity and carrying it to the international level, the influence would be more effective.

The proposal is to establish a Global Water Security Council (GWSC) to monitor, regulate and implement the water conventions and agreements (Figure 10), where each country has such a local entity that should be under the umbrella of the GWSC.

The ultimate goal for the GWSC is to lead and ensure sustainable transformation for water conflict; the local WSC will include two wings, one for the academic level and other for the political 
level, and each would have different functions and tasks. The academic level will be responsible for research and development, field monitoring and documentation, organizing workshops and conferences and increasing awareness and water education, which is a rather important for future orientation. The political level will be responsible for setting a healthy environment for cooperation, leading the negotiation and finding mutual interests, conducting agreements and ensuring a sustainable relationship. The media would also play a significant role to mitigate the risk of spreading fears and inform the public about the progress of the WSC and the transparency of the workflow, activities, initiatives and achievements.

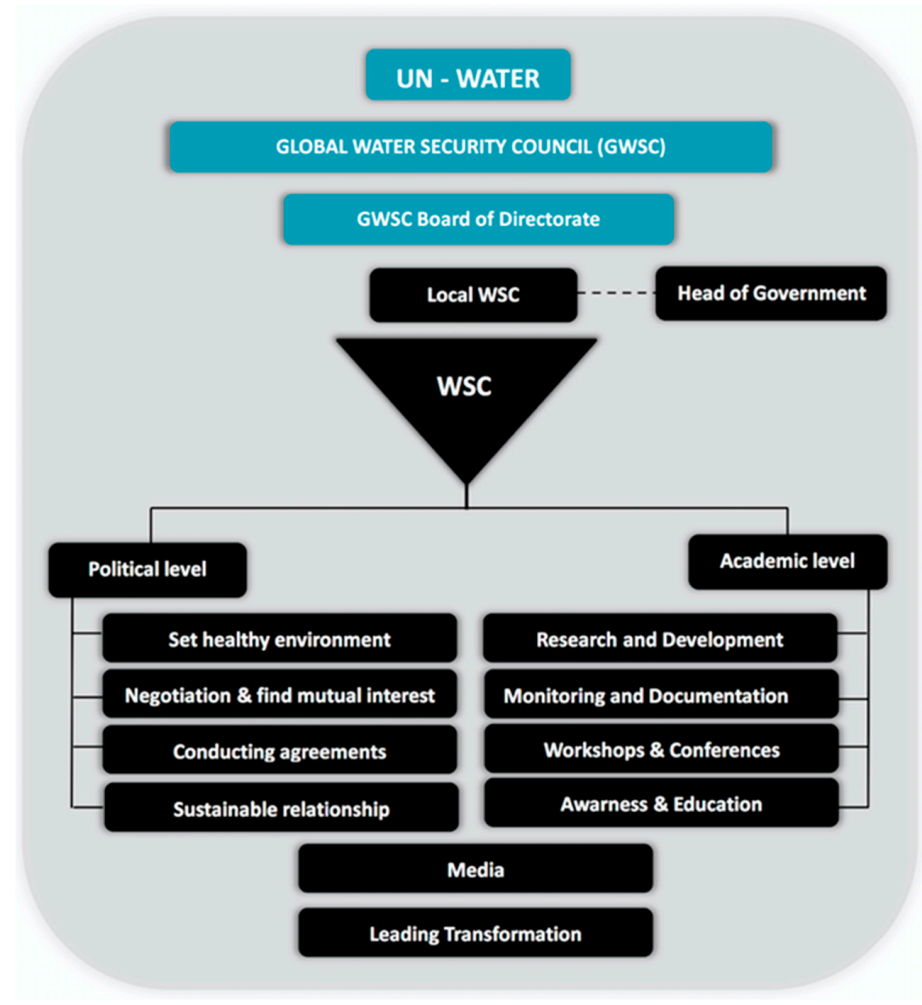

Figure 10. The proposed Global Water Security Council organization structure.

\section{Discussion}

Globally, there is a trend of waging propaganda and spreading phobia of water wars; there is a fear of the chance of such trend being used by an irrational regime, using perhaps military action as a solution. Such propaganda would feed the fire and drive the nations to the wrong direction, ending with actual disputes. Due to this the opportunities for disputes between countries over water rights and water access have been increasing dramatically; the countries that are rich in water will hold more power than countries that do not have a lot of water. Wars would be waged over who gets to control sources of water, because water would equate to wealth. In this context the political decision and influence will play a significant role to create peace or wage a sort of conflict.

The conflict is usually avoided as long as it is possible, where most of the water battles nowadays are conducted in the court. With cooperation and modern technologies, conflict can be avoided; however, this concept is valid when talking about more affluent nations. Countries with less resources and no access or room for legal processing are more prone to finding themselves in a violent war over water. The injustice then will make desperate people more likely to take water by force. It will be up to the water controller to realize that it may be better to not cut-off water completely, rather negotiates an agreement that everyone could live with. Therefore, developing the level of understanding the negotiations benefit within the ETB countries will help to mitigate the risk of conflict and guide them to mutual interests. 
Water shortage or scarcity will not be the sole factor in instigating violence; another element, for example, is that the media could play a significant role to create panic and fear by coupling the term of war with water. It could be viewed as political or business propaganda spreading alarm; it could be to the advantage of the dam construction industry or for regulating new roles or even for political enforcement, while others may perceive it as a realistic description of the future. However, there is no winner in such a war; rather there are two losers, and one of them might lose more than other.

Although the GAP completion in ETB looks like bringing the upstream country to a stronger position, at the same time it is considered as a security burden as well. In terms of the region, in particular, the upstream country now has something to protect and worry about (the GAP zone). Usually the dam's zone is considered as a sensitive area from the security perspective; it could be very risky in terms of natural disasters; especially earthquakes are very common in the region. In addition, dams could be an easy target for terrorists to threaten and control the region. A very good example is the occupation of the dams in Syria and Iraq by ISIS. Since the region is characterized with a fragile security system, the GAP would add a collectively security burden for both the upstream and downstream countries, respectively. To avoid long-term consequences, the upstream country cannot protect in their own way without involving or consulting the downstream, and this is a geopolitical and technical mutual point of interest for the three countries.

This might shift the bargaining power from the unipolar order (upstream country) and share it with the downstream countries to have a multi-polar order of bargaining power. This is possible because the three countries now share the same security concern due to the wide range of impact of the GAP, which is definitely spread across the political borders. This is exactly where GAP completion could be an opportunity rather than a subject of conflict; by a deep rational understanding of the riparian countries' water bargaining power this could turn the negotiation to be more integrative and could act as a springboard for long-term collaboration.

It has been recognized that Issue-Linkage as an approach is no longer an option and it is not the proper tool for the long-run; rather it spreads distrust between the riparian countries, nations and consolidates instability in the region. Contrarily, Benefit-Linkage would tie the riparian countries with socio-economic strategic commitments. This might be the reason why the water tension between Iraq-Turkey might be lighter than the one between Syria-Turkey, since Iraq-Turkey were mostly using the Benefit-Linkage approach to manage the conflict states. Here the importance of the sustainable tools for the transformation stages is recognized where the mutual agreements should be always linked to incentives to guarantee a stable partnership for the three countries.

Another advantage for the GAP completion is that the downstream will be encouraged to practice better management by using innovative technologies and conservation methods. By implementing the Development-Linkage approach, the more developed a country is in terms of integrated water management, the more water allocation will be offered. In this context, the competition will become healthy, and the suggested three-stage plan by the upstream country for water allocation could be adjusted in that direction. One of the key proposed projects for the GWSC is to establish the Dam Index Concept (DIC); obviously, building massive dams is a global concern, since these dams are the elements for water control. Therefore, the less constructed dams, the better it would help to reduce the risk of water control. This would stop the trigger in the very early phase of the hydropolitical cycle. The DIC will include several parameters to be checked and evaluate whether any newly constructed massive dam is needed. These parameters include and are not limited to the five phases indicated in the hydropolitical cycle, previously described. Upon approval, the dam will be remotely monitored on a daily basis by satellite to ensure the security and purpose for which it has been established. The DIC will be proposed to be studied in depth in the future in a separate work and the framework will match with the Sustainable Development Goals (SDGs).

Nevertheless, the author believes that the phobia of water conflict between the riparian countries of the ETB might be exaggerated, as the ETB players have many more pros than cons to cooperate, especially when it comes to the national security, where the region is facing a significant threat in terms 
of terrorism. Ethically, there are some moral bonds between the nations indicated by the common history, culture and rights of neighborhood that make them prefer more face-to-face dialogue to build understanding, break the distrust, if any, and seize the chance for potential and strategic partnership.

Currently, there are many positive indicators in the ETB to have a better environment to enter into promising agreements. In January 2019, there was an indirect discussion between Syria and Turkey, moderated by Russia, to reactivate the protocol of 1998, after seven years of disconnection between the two countries; the relationship between both has been developed over ten years right after the 1998 protocol to reach the peak, until 2011, where the uprising in Syria turned the relationship into a severe conflict. The cooperation between Iraq and Turkey on the water resource has been significantly improved. In 2018, Iraq was suffering from a drought year; with good communication, Turkey postponed the storing of the Ilisu dam as a good intention for cooperation and neighborhood. In March 2019, Iraq witnessed heavy seasonal rains caused flooding and damages; the government crisis cells have been activated in federal Iraq. Despite the limited budget and capacity after the ISIS invasion, the local staff of Iraqi Ministry of Water Resources was managing the crisis in a very good manner. Turkey officially announced that it is ready to help with every possible means. Recently, Baghdad and Ankara exchanged high-level delegations. In May 2019, the Iraqi Prime Minister, upon official invitation from the Turkish President, visited Ankara to strengthen bilateral relations. The water challenges, economic and security cooperation were on the top of the discussion list.

Funding: This research received no external funding.

Acknowledgments: The author is very thankful to the academic program of Water Conflict Management and Transformation at the College of Earth, Ocean, and Atmospheric Sciences at Oregon State University for the fruitful discussions, excellent management and organization. The dedication of this work goes also to the Iraqi Public Leadership program which has been hosted by the American University of Sharjah-UAE and sponsored by Crescent Petroleum. Special thanks go to Yass Alkafaji for the motivation and breeding hope where these seeds will grow for generations and to Majid Jafar for his vision for conceiving the idea and for his generosity in sponsoring the program for seven years.

Conflicts of Interest: The author declares no conflict of interest.

\section{References}

1. Carkoglu, A.; Eder, M. Domestic concerns and the water conflict over the Euphrates-Tigris river basin. Middle East. Stud. 2001, 37, 41-71. [CrossRef]

2. El-Fadel, M.; El Sayegh, Y.; Abou Ibrahim, A.; Jamali, D.; El-Fadl, K. The EuphratesœTigris Basin: A Case Study in Surface Water Conflict Resolution. J. Nat. Resour. Life Sci. Educ. 2002, 31, 99-110.

3. Kibaroğlu, A. Water for Sustainable Development in the Euphrates-Tigris River Basin. Middle East Technical University Department, 2004. Available online: https://www.iraqicivilsociety.org//wp-content/uploads/2013/ 02/waterforsustainableAKibaroglu.pdf (accessed on 28 September 2019).

4. Daoudy, M. Benefit-sharing as a tool of conflict transformation: Applying the Inter-SEDE model to the Euphrates and Tigris river basins. Econ. Peace Secur. J. 2007, 2. [CrossRef]

5. Daoudy, M. Asymmetric power: Negotiating water in the Euphrates and Tigris. Int. Negot. 2009, 14, 361-391. [CrossRef]

6. Harris, L.M.; Alatout, S. Negotiating hydro-scales, forging states: Comparison of the upper Tigris/Euphrates and Jordan River basins. Political Geogr. 2010, 29, 148-156. [CrossRef]

7. Kibaroglu, A.; Scheumann, W. Euphrates-Tigris Rivers System: Political Rapprochement and Transboundary Water Cooperation; Turkey's water policy; Springer: Berlin/Heidelberg, Germany, 2011; pp. 277-299.

8. Al, O.; Jawad, A.H.M.; Al-Khateeb, M. The challenges of water sustainability in Iraq. Eng. Technol. J. Part A Eng. 2013, 31, 828-840.

9. Hommes, L.; Boelens, R.; Maat, H. Contested hydrosocial territories and disputed water governance: Struggles and competing claims over the Ilisu Dam development in southeastern Turkey. Geoforum 2016, 71, 9-20. [CrossRef]

10. Conker, A. The power struggle in the layer of transnational hydropolitics: The case of the Ilisu dam project. Eurasian J. Soc. Sci. 2016, 4, 14-34. [CrossRef] 
11. Conker, A. An Enhanced Notion of Power for Inter-State and Transnational Hydropolitics: An Analysis of Turkish-Syrian Water Relations and the Ilısu Dam Conflict between the Opponents and Proponents of the Dam. Ph.D. Thesis, University of East Anglia, Norwich, UK, 2014.

12. Lossow, T.V. Water as Weapon: IS on the Euphrates and Tigris: The Systematic Instrumentalisation of Water Entails Conflicting IS Objectives. 2016, Volume 8. Available online: https://www.swp-berlin.org/fileadmin/ contents/products/comments/2016C03_lsw.pdf (accessed on 28 September 2019).

13. Zeitoun, M.; Mirumachi, N.; Warner, J. Transboundary water interaction II: The influence of 'soft' power. Int. Environ. Agreem. Politics Law Econ. 2011, 11, 159-178. [CrossRef]

14. Hussein, H.; Menga, F.; Greco, F. Monitoring transboundary water cooperation in SDG 6.5. 2: How a critical hydropolitics approach can spot inequitable outcomes. Sustainability 2018, 10, 3640. [CrossRef]

15. Wahlstrom, M.; Guha-Sapir, D. The Human Cost of Weather-Related Disasters 1995-2015; UNISDR: Geneva, Switzerland, 2015.

16. Food and Agriculture Organization of the United Nations. Water \& Poverty, an Issue of Life \& Livelihoods, Water Scarcity. 2013. Available online: http://www.fao.org/nr/water/issues/scarcity.html (accessed on 28 September 2019).

17. World Water Assessment Programme (United Nations) and UN-Water. Water in a Changing World; Earthscan: London, UK, 2009; Volume 1.

18. Food and Agriculture Organization of the United Nations. The State of Food Security and Nutrition in the World 2017: Building Resilience for Peace and Food Security; FAO: Rome, Italy, 2017.

19. Gleeson, T.; Wada, Y.; Bierkens, M.F.; van Beek, L.P. Water balance of global aquifers revealed by groundwater footprint. Nature 2012, 488, 197. [CrossRef] [PubMed]

20. Unicef. Advancing WASH in Schools Monitoring; United Nations Childrens Fund: New York, NY, USA, 2015.

21. Wasserbauten, A. Landwirtschaftliche Wasserbauten im Kernland Assyriens Zwischen Der 2. Hälfte Des 2. Und 1. Hälfte Des 1. Jahrtausends v. Chr. 2000. Available online: https://www.amazon. com/Assyrische-Wasserbauten-Landwirtschaftliche-Jahrtausends-Forschungen/dp/3805326394 (accessed on 28 September 2019).

22. Priscoli, D.J.; Wolf, T.A. Managing and Transforming Water Conflicts; Cambridge University Press: Cambridge, UK, 2009.

23. Al-Muqdadi, S.W.; Omer, M.F.; Abo, R.; Naghshineh, A. Dispute over Water Resource Management Iraq and Turkey. J. Environ. Prot. 2016, 7, 1096-1103. [CrossRef]

24. Wilson, R. Water-Shortage Crisis Escalating in the Tigris-Euphrates Basin. Future Directions International. 2012. Available online: http://futuredirections.org.au/wp-content/uploads/2012/08/FDI_Strategic_Analysis_ Paper_-_28_August_2012(1).pdf (accessed on 13 December 2018).

25. United Nation. Treaty of Friendship and Neighbourly Relations between Iraq and Turkey, Collection of Treaties. No. 1946. Volume 580, pp. 281-331. Available online: http://www.internationalwaterlaw.org/ documents/regionaldocs/Iraq-Turkey-Friendship_1946.pdf (accessed on 30 August 2019).

26. Bari, Z. Syrian-Iraqi dispute over the Euphrates waters. Int. Stud. 1977, 16, 227-244. [CrossRef]

27. Drysdale, A. Ba'th v. Ba'th: The Conflict between Syria and Iraq, 1968-1989, by Eberhard Kienle (Book Review). Middle East J. 1992, 46, 690.

28. Jongerden, J. Dams and politics in Turkey: utilizing water, developing conflict. Middle East Policy 2010, 17, 137-143. [CrossRef]

29. Büssra, K. 2018, EU's Turkey Decision More Challenging with Lisbon Treaty-Analysis, Ahval News. Available online: https://ahvalnews.com/eu-turkey/eus-turkey-decision-more-challenging-lisbon-treatyanalysis (accessed on 19 June 2018).

30. Turkey Foreign Policy and Government Guide, 2nd ed.; International Business Publications: USA, 2009; 300p. Available online: https://www.amazon.com/Turkey-Foreign-Policy-Government-Guide/dp/0739762826 (accessed on 28 September 2019).

31. Yuksel, I. Water development for hydroelectric in southeastern Anatolia project (GAP) in Turkey. Renew. Energy 2012, 39, 17-23. [CrossRef]

32. Yuksel, I. South-eastern Anatolia Project (GAP) factor and energy management in Turkey. Energy Rep. 2015, 1, 151-155. [CrossRef]

33. South-Eastern Anatolia Project GAP. Official Website. 2018. Available online: http://www.gap.gov.tr/en/ upload/dosyalar/files/Statistical_Data/POPULATION.pdf (accessed on 31 July 2019). 
34. Mutlu, S. Population of Turkey by ethnic groups and provinces. New Perspect. Turk. 1995, 12, 33-60. [CrossRef]

35. Duboz, R.; Echaubard, P.; Promburom, P.; Kilvington, M.; Ross, H.; Allen, W.; Ward, J.; Deffuant, G.; de Garine-Wichatitsky, M.; Binot, A. Systems thinking in practice: Participatory modeling as a foundation for integrated approaches to health. Front. Vet. Sci. 2018, 5, 303. [CrossRef]

36. Bacharach, S.B. Negotiation Skills Course|Cornell University; Cornell University: Ithaca, NY, USA, 2016.

37. Fisher, R.; Ury, W.L.; Patton, B. Getting to Yes: Negotiating Agreement without Giving in; Penguin: London, UK, 2011.

38. Bacharach, S.B.; Lawler, E.J. Bargaining: Power, Tactics and Outcomes; Jossey-Bass Inc.: San Francisco, CA, USA, 1981.

39. Wolf, A.T. Healing the enlightenment rift: Rationality, spirituality and shared waters. J. Int. Aff. 2008, 51-73.

40. UNDP. Report. 2018. Available online: https://www.undp.org/content/dam/undp/library/Climate\%20and\% 20Disaster\%20Resilience/Climate\%20Change/Arab-States-CCA.pdf (accessed on 26 October.2018).

41. United Nation. General Assembly 28 Session, Resolution 3129 Decl.2 and 3, Cooperation in the Field of Environment Concerning Natural Resources Shared by Two or More States; United Nation: New York, NY, USA, 1973.

42. Van Veenen, J. Dealing with Miscommunication, Distrust, and Emotions in Online Dispute Resolution. 2010. Available online: https://papers.ssrn.com/sol3/papers.cfm?abstract_id=1626212 (accessed on 28 September 2019).

43. Barsness, J.A. US Political Transition Policy and Post-2003 Violence in Iraq. Ph.D. Thesis, Georgetown University, Washington, DC, USA, 2012.

44. Kelly, M.J. The tricky nature of proving genocide against Saddam Hussein before the Iraqi Special Tribunal. Cornell Int'l LJ 2005, 38, 983.

45. Richardson, C.J.; Reiss, P.; Hussain, N.A.; Alwash, A.J.; Pool, D.J. The restoration potential of the Mesopotamian marshes of Iraq. Science 2005, 307, 1307-1311. [CrossRef] [PubMed]

46. Kelley, J.R.; Wakeley, L.D.; Broadfoot, S.W.; Pearson, M.L.; McGrath, C.A.; McGill, T.E.; Jorgeson, J.D.; Talbot, C.A. Geologic Setting of Mosul Dam and Its Engineering Implications (No. ERDC-TR-07-10); Engineer Research and Development Center: Vicksburg, MS, USA, 2007.

47. Milner, A. Mosul Dam: Why the battle for water matters in Iraq. BBC News 2014, 18. Available online: https://www.bbc.com/news/world-middle-east-28772478 (accessed on 29 September 2019).

48. Riley, G.Z. The Last Free River of Mesopotamia. Ph.D. Thesis, Utrecht University, Utrecht, The Netherlands, 2014.

49. Republic of Iraq. Iraqi Constitution. Article 110 and Article 114. 2005. Available online: http://www. iraqinationality.gov.iq/attach/iraqi_constitution.pdf (accessed on 05 May 2016).

50. BBC. Interview Masoud Barazani. 2017. Available online: https://www.bbc.com/news/world-middle-east41189619 (accessed on 30 August 2018).

51. Conker, A.; Hussein, H. Hydraulic Mission at Home, Hydraulic Mission abroad? Examining Turkey's Regional ‘Pax-Aquarum'and Its Limits. Sustainability 2019, 11, 228. [CrossRef]

52. Green, E.A. Hydropolitics in the Middle East and US Policy; Naval War College: Newport, RI, USA, 1993.

53. Hussein, H. Yarmouk, Jordan, and Disi basins: Examining the impact of the discourse of water scarcity in Jordan on transboundary water governance. Mediterr. Politics 2019, 24, 269-289. [CrossRef]

54. Hussein, H. Whose 'reality'? Discourses and hydropolitics along the Yarmouk River. Contemp. Levant 2017, 2, 103-115. [CrossRef]

55. UNESCO. Marshland-Iraq. 2016. Available online: https://whc.unesco.org/en/list/1481 (accessed on 13 January 2017).

56. Dailysabah. 2019. Available online: https://www.dailysabah.com/economy/2019/06/21/ankara-eager-tomaximize-economic-ties-with-baghdad-in-all-areas (accessed on 15 July 2017).

(C) 2019 by the author. Licensee MDPI, Basel, Switzerland. This article is an open access article distributed under the terms and conditions of the Creative Commons Attribution (CC BY) license (http://creativecommons.org/licenses/by/4.0/). 